\title{
Evaluation of Mango Seed kernel Extract as natural occurring phenolic rich antioxidant compound
}

\section{Talaat M.A El-Kady*, Mohamed K. Abd El-Rahman*, A.O.Toliba**, Samy M. Abo El-maty**}

* National Nutrition Istitute, Ministry of health and population, Cairo, Egypt

** Food Sci. Dept., Fac. Agric., Zagazig Univ., Egypt

\section{ABSTRACT}

Uunflower oil (SFO) seeds of Helianthus annuus L., is a rich source of linoleic acid, which is more susceptible to oxidation of edible oils. Usually antioxidant materials are added to improve the oxidative stability of oils .Mango seeds kernels (MSK) are a sources rich with natural antioxidant compounds. In 2012, the bio-waste was produced by processing industries of mango fruits around 3,932 $\mathrm{mT}$ in Egypt. Ethnolic extract of mango seed kernel (MSKE) has been used for stabilization of SFO at three concentrations $(\mathrm{mg} / \mathrm{kg}$ oil) i.e., 200(MSKE-200), 500(MSKE-500) and1000 ppm (MSKE -1000), while BHT was used at a level of 200ppm (BHT-200) for comparison. Progression oxidation of $S F O$ was followed during accelerated storage at $70^{\circ} \mathrm{C}$ for $72 \mathrm{hr}$ (at intervals of 4 hr)by measuring oxidative stability tests: peroxide value( $P V)$, $p$-anisidene value $(P$-anv), total oxidation value (TOTOX), acid value (AV) and thiobarbituric acid reactive substances (TBARS) . Results of HPLC analysis of MSKE showed that contained 20 compounds of total phenolic content. MSKE at 100ppm had the highest radical-scavenging activity (96.86\%) followed by BHT (94.9\%) and ascorbic acid (91.5\%). The higher levels of MSKE (1000, 500 ppm) provide the best protection against primary and secondary oxidation of SFO samples. The different parameters of oxidative stability were in agreement with each other, suggesting higher efficiency of 1000ppmMSKE > 500ppm MSKE > 200ppm BHT> 200ppm MSKE > control.

Key words: mango seed, sunflower oil, oxidative stability. 


\section{INTRODUCTION}

Sunflower oil (seeds of Helianthus annuus L.) is widely used in nutrition as a source of essential linoleic (9-cis, 12-cisoctadecadienoic) acid. Edible oils with higher contents of unsaturated fatty acids, especially polyunsaturated fatty acids, are more susceptible to oxidation (Mariana-AtenaPoiana., 2012). Lipid oxidation is the main deterioration process that occurs during thermal processing of vegetable oils containing lipid molecules with poly unsaturation (EI Anany et al., 2007).

The addition of antioxidants is considered as one of the methods of increasing shelf life of lipids and lipid-containing foods. Synthetic antioxidant, such as butylated hydroxyl anisole (BHA) and butylated hydroxyl toluene (BHT), have restricted use in foods as these synthetic antioxidants are suspected to be carcinogenic (Jayaprakasha et al., 2001). Due to these safety concerns, there is an increasing trend among food scientists to replace these synthetic antioxidants with natural ones, which, in general, are supposed to be safer (Yanishlieva and Marinova, 2001). Antioxidants (natural and synthetic) play a significant role in retarding lipid oxidation reactions in food products. The detrimental effects of excessive lipid oxidation, such as formation of off-flavors and undesirable oxidized chemical compounds (aldehydes, ketones and organic acids) are well known (Saad et al., 2007). A number of natural antioxidants have been added during food processing and have elongated the shelf life and oxidative stability of stored products (Jang et al., 2012). The main classes of natural antioxidant compounds in nature are flavonoids and phenolic acids in free or complexes forms. These compounds have been identified and quantified in several fruits and vegetables, and show a high correlation with antioxidant activity (Einbond et al., 2004). According to FAO estimates (FAOSTAD, 2015), world production of mango was 42,139,837 mT. Approximately, $0.5 \%$ of world mango production is used to obtain derived products; therefore the amount of bio-waste produced by processing industries is estimated to be around 210,000 
mT worldwide. In 2012 the amount of bio -waste produced by processing industries in Egypt is estimated to be around 3,932 $\mathrm{mT}$. Environmental, hygienic, and public health problems result in unorganized management of this waste. The objective of this study was to evaluate the antioxidant activity of mango kernel seeds extract on SFO stability.

\section{MATERIALS \& METHODS}

\section{Materials}

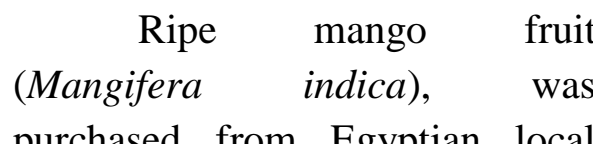
purchased from Egyptian local market, Cairo Egypt. Ten liters of refined bleached and deodorized (RBD) sunflower oil (SFO) free of additives was obtained from Company for Oil and Soap, Tanta, Egypt.

All chemicals used in the study, such as Gallic acid, FolinCiocalteu reagent and Wijs' solution and butylated hydroxyl toluene (BHT) were purchased from Merck (Darmstadt, Germany). Potassium Ferricyanide, Potassium Phosphate, Sodium Carbonate, Sodium Hydroxide Ethanol, Methanol, Chloroform, Diethyl Ether, Petroleum Ether, Acetic acid, Sodium Thiosulfate, Boric acid, Sulfuric acid, Potassium Iodide, Aluminum Chloride, Trichloroacetic acid, Ferric Chloride and Hydrochloric acid were purchased from Fisher Scientific (Leicestershire,UK).

$$
\text { 2,2-diphenyl- } 1 \text { - }
$$

picrylhydrazyl (DPPH); 1, 1, 3, 3tetraethoxypropane ,Ascorbic acid, Acetonitrile and Standard (phenolic and flavonoid) compounds were purchased from Sigma-Aldrich (St. Louis, MO).

\section{Methods}

\section{Sample preparation}

Mango kernel stones were removed manually and separated from the pulp, then washed with excess water to remove adhering materials. The stones were opened to get kernels. Mango kernels were cut cross-section wise into thin slices before extraction. Mango seed kernels pieces were spread in single layer for drying in an electric oven at $40^{\circ} \mathrm{C}$ for 24 hours. The dried mango kernels were milled with grinder, then mango seed kernels were heated in an electric oven at $160^{\circ} \mathrm{C}$ for 20 min to improve the yield of phenolic compound (Soong and Barlow 2004). According to the 
extract method of El Anany, (2015) ten grams of fruit seeds powder were extracted overnight with $1000 \mathrm{ml}$ of $80 \%$ ethanol solution in a shaking incubator $(100 \mathrm{rpm})$ at room temperature. Then the extracts were centrifuged at $3500 \mathrm{rpm}$ for $15 \mathrm{~min}$. The supernatants were filtered through a Whatman No.1 filter paper, then extract solutions were concentrated to dryness in a rotary evaporator at $40^{\circ} \mathrm{C}$ and stored at $20^{\circ} \mathrm{C}$ for further use.

\section{Sample preparation for accelerated oxidative storage}

A known weight of the dry extract was dissolved in ethanol and addition to SFO as a source of antioxidant. The extract of mango seed kernel (MSKE) was applied to RBD edible SFO (free of any synthetic antioxidants) at different concentrations (200, 500 and 1000 ppm, based on extract weight), in a series of glass bottles having a volume of $100 \mathrm{ml}$ each, to examine their antioxidative activity. BHT at a level of 200 ppm was also applied for comparison. The bottles were completely filled with oil and sealed. A control sample was prepared by using the same amount of ethanol used to dissolve the antioxidant and the extracts (Mohdaly et al., 2010). The antioxidant enriched oil samples were evaporated in a rotary evaporator below $40 \quad{ }^{\circ} \mathrm{C}$ to evaporate the solvent and subjected to accelerated oxidation in dark oven at $70^{\circ} \mathrm{C}$ for $72 \mathrm{hr}$ (Fennema, 1976). One hundred $\mathrm{ml}$ of each oil sample was taken for oxidative analysis of (PV, Pan, $\mathrm{AV}$ and TBARS), at $4 \mathrm{~h}$ intervals for analysis. Immediately after storage period, oil samples were withdrawn for triplicate analyses. Oil sampled were taken for each measurement from separate bottle.

\section{Chemical Composition of seeds}

Moisture, protein, ash, crude fiber and ether extract in the mango seed kernel were determined according to AOAC (2005) methods. The nitrogen free extract was calculated by difference on dry weight basis.

\section{Determination of phenolic content}

Total phenolic content of the extract was measured using the Folin-Ciocalteu assay developed by Singleton and Rossi (1965). This is a colorimetric assay, involving production of a blue 
molybdenum tungsten complex in the presence of phenolics which can be measured relative to gallic acid as the standard. Aqueous Folin -Ciocalteu reagent (1:10) was added to the kernel extract or the standard, incubated for $5 \mathrm{~min}$ before addition of $0.115 \mathrm{mg} / \mathrm{ml}$ of $\mathrm{Na}_{2} \mathrm{CO}_{3}$. After $2 \mathrm{~h}$ incubation period, absorbance was read at $765 \mathrm{~nm}$ using a spectrophotometer ( Unicam, Helios Alpha, UK). Gallic acid was used as standard and calibration curve was plotted in concentration range $50-200$ $\mathrm{mg} / \mathrm{l}$. Results were expressed as $\mathrm{mg}$ of Gallic acid equivalents/g dried seeds.

\section{Determination of flavonoid content}

Flavonoid content was determined according to the procedure described by Zhishen et al., (1999). Solutions of the extracts in Methanol $80 \%$ were prepared to give a final concentration of $6 \mathrm{mg} / \mathrm{ml}$. Each solution $(5 \mathrm{ml})$ was mixed with 0.3 $\mathrm{ml}$ of $5 \%$ aqueous $\mathrm{NaNO}_{2}(\mathrm{w} / \mathrm{v})$ and allowed to stand at room temperature for $5 \mathrm{~min}$; $0.6 \mathrm{ml}$ of $10 \% \quad \mathrm{AlCl}_{3}$ solution $(\mathrm{w} / \mathrm{v})$ was added to the mixture. After 6 $\min , 2 \mathrm{ml}$ of $1 \mathrm{M} \mathrm{NaOH}$ and $2.1 \mathrm{ml}$ of water were added to the mixture. The absorbance was measured at $510 \mathrm{~nm}$ using a spectrophotometer (Unicam, Helios Alpha, UK). The results were expressed as mg quercetin (Q) equivalents per $100 \mathrm{~g}$ of dry mater.

\section{Free radical scavenging activity}

The free radical scavenging activity of the extract was measured by using 2,2-diphenyl2-picryl hydrazyl (DPPH) method as described by Yang et al., (2009) with some modifications. Briefly, $0.1 \mathrm{ml}$ of samples $(100 \mu \mathrm{g} / \mathrm{ml}$ in $80 \%$ methanol) was added to $3.9 \mathrm{ml}$ of $0.2 \mathrm{mM}$ DPPH methanolic solution. The reaction mixture was agitated and allowed to stand at room temperature in dark for $30 \mathrm{~min}$. The absorbance at $515 \mathrm{~nm}$ was used to measure the concentration of the remaining DPPH using a spectrophotometer (Unicam, Helios Alpha,UK). Ascorbic acid and BHT $(100 \mu \mathrm{g}$ $/ \mathrm{ml}$ in each methanol) were used as positive control, the percentage inhibition of the DPPH radical was calculated according to the following formula: 
$\%$ Inhibition $=((\mathrm{A}$ control -A sample) / A control) X 100

Where: A is absorbance

\section{Determination of reducing power}

The reducing power of the extracts was measured as described by Oyaizu (1986). The reaction mixture contained $1.0 \mathrm{ml}$ of extract, $1.0 \mathrm{ml}$ of $0.2 \mathrm{M}$ phosphate buffer ( $\mathrm{pH}$ 6.6) and1.5 $\mathrm{ml}$ of potassium ferricyanide $(1 \%$, $\mathrm{w} / \mathrm{v}$, in water). The mixture was incubated at $50^{\circ} \mathrm{C}$ for $30 \mathrm{~min}$ and the reaction was stopped by addition of $1.5 \mathrm{ml}$ of tri chloroacetic acid $(10 \%, w / v$, in water), followed by centrifugation at $980 \mathrm{~g}$ for $10 \mathrm{~min}$. Aliquots of 2 $\mathrm{ml}$ of the supernatant were mixed with $2 \mathrm{ml}$ of distilled water and 0.5 $\mathrm{ml}$ of ferric chloride $(0.1 \%$, w/v, in water) and the absorbance was measured at $700 \mathrm{~nm}$, using spectrophotometer (Unicam, Helios Alpha,UK), against blanks that contained all reagents except the sample extracts.

\section{Ferric reducing antioxidant power (FRAP) assay}

The FRAP assay of the MSKE was carried out according to the procedure of-Benzie and
Szeto, (1999). One hundred micro liters of the diluted extract in methanol (conc.) was added to $3 \mathrm{ml}$ of the FRAP reagent. After 4 min, the absorbance of the mixture was measured at $593 \mathrm{~nm}$ using UV/VIS spectrophotometer (Unicam, Helios Alpha, UK). A calibration curve was prepared using BHT as a standard at 200, 400, 600, 800 and $1000 \mu \mathrm{m}$. FRAP values were expressed on a fresh weight basis as micromoles of BHT equivalent per gram of sample ( $\mu \mathrm{m}$ BHT equivalent/g dry weight).

\section{Identification of phenolic acids using HPLC}

Phenolic acids of the dried extract were identified according to the method described by Janas et al., (2009). Shimadzu HPLC system (Shizadzu Corp., Kyoto, Japan) comprising an LC-10AD pump, SCTL 10A system controller and SPD 10A photodiode array detector. Each sample was first filtered through a $0.45 \mu \mathrm{m}$ nylon membrane and then injected onto a prepacked LiChrospher 100RP-18 column (4 x $250 \mathrm{~mm}, 5 \mu \mathrm{m}$; Merck, Darmstad Germany). The mobile phase consisted of water, 
acetonitrile, acetic acid (88:10:2; $\mathrm{v} / \mathrm{v} / \mathrm{v})$ the flow rate, was $1 \mathrm{ml} /$ min, and detection of phenolic acid was monitored at $320 \mathrm{~nm}$.

Oxidative stability tests

Peroxide value (PV)

$\mathrm{PV}$ was determined according to the standard method of IUPAC (1987).

\section{Measurement of P-Anisidin value} (P-anV)

P-anV was determined
according to AOCS method
(1995).

\section{Total oxidation value (TOTOX)}

TOTOX values of the oil samples were determined based on the obtained PV and p-an values (Nyam et al., 2013). Values were calculated using the following Equation: $\quad$ TOTOX $=2 \mathrm{PV}+\mathrm{P}$ anV

Acid value (AV)

AV was determined according to AOCS method (1995).

Thiobarbituric Acid Reactive Substances (TBARS) assay

The Thiobarbituric Acid test was based on the color reaction of TBA with malondialdehyde (MDA) $\mathrm{mg} / \mathrm{kg}$ in the sample (David, 1976). The absorbance was measured at 531 $\mathrm{nm}$ against the blank solution (distilled water). A standard curve of MDA was prepared using 1, 1, 3, 3-tetraethoxypropane. TBARS values were expressed as mg of MDA per $\mathrm{kg}$ of sample.

\section{RESULTS \& DISCUSSION}

Proximate composition: The results in Table1, showed the chemical composition of MSK powder showed its contents of crude protein, total lipid, crude fiber and ash were found to be $6.9 \%, 12.5 \%, 2.9 \%$ and $2.3 \%$, on a dry weight basis, respectively, moisture content was $8.1 \%$. These results are close to those reported by (Abdalla et al., 2007), who reported that the moisture content of dried MSK powder samples was $8.1 \%$. Crude protein, total lipid, crude fiber and ash contents of MSK were $6.7 \%, 12.3 \%, 2.7 \%$ and $2.5 \%$ on dry weight basis, respectively. The total lipid content in this study was higher than that showed by others as Youssef,( 1999). This may be due to different mango varieties. 
The yield of extract from mango seed kernel powder showed in Table 2 was 9.43 $\mathrm{g} / 100 \mathrm{~g}$ powder. Jung et al., ( 2006) compared the influence of different solvents on total phenolic and total flavonoid extracted from ginseng leaves and they found that, the ethanol extracts contained higher amounts of total phenolic and Flavonoids (2333 and 1199 $\mathrm{mg} / 100 \mathrm{~g}$ resp.) than water $(1932$ and $503 \mathrm{mg} / 100 \mathrm{~g}$ resp.)and methanol extracts (2286 and 720 $\mathrm{mg} / 100 \mathrm{~g}$ resp.). The ethanolic extracts of heated MSK at $160^{\circ} \mathrm{C}$ for $20 \mathrm{~min}$ were showed increase in the total phenolic content from 50.3 to $160 \mathrm{mg} \mathrm{GAE} / \mathrm{g}$ (Soong and Barlow, 2004). This increase could be due to the release of more bound phenolics from the breakdown of cellular constituents due to the thermal treatment (Gallegos-Infante et al., 2010) and to the degradation of polymerized polyphenols, specifically hydrolysable tannins, and the hydrolysis of other glycosylated flavonoids (Monagas et al. 2009). Roasting process caused significant decreases in the nutritional factors (Tannins and phytic acid) content (El Anany, 2015). Likewise, in a study on acorn nut Gallic acid increased after thermal treatment to almost 2-fold its content $(0.142$ to $0.270 \%$ ) in a dry powder extract (Rakic et al., 2006). Pyrroles and furans which are the major compounds formed by the Maillard reaction may contribute to the increased in total phenolic compounds of roasted samples (Yanagimoto et al., 2002). They were reported an increased in the antioxidative function due to the generation and accumulation of Maillard-type antioxidants (MRP) during the heating process. This suggestion was confirmed by (Antonio et al., 2003) who showed an increase in the optical density of at $280 \mathrm{~nm}$, in plums dried at 60 or $85^{\circ} \mathrm{C}$.

\section{Total phenolic content}

Polyphenols are phytochemicals from plants and are being used for prevention of various diseases that are mainly caused by free radicals. The higher polyphenol content would then exhibit stronger inhibition and also higher antioxidant activity (Jayaprakasha et al., 2003). Results in table 2 showed that, total phenolic content of the extract from mango seeds was 
$21.29 \mathrm{mg} / \mathrm{g}$ on dry basis. The result of total phenolic content of mango seed kernels are in agreement with those of Thai mango which contained 11-28.62 $\mathrm{mg}$ gallic /g (Pitchaon, 2011) and 28.33- 44.76mg gallic/g (Eva Dorta et al., 2014). The technique of phenolic isolation from plant material, including the methods and type of extracting solvent, depends generally on the type of phenolic compound and the solvents (Goli et al., 2004).

\section{Total flavonoid content}

Flavonoids are the most common and widely distributed group of plant phenolic compounds (Guo et al., 2012) and are generally categorized as phenolics depending on their chemical structure (Sung and Lee, 2010). Results in table 2 showed that, mango seeds contained $22.20 \mathrm{mg}$ total flavonoids/g dw. Total flavonoids contents different conditions depend on extracting methods and sources of seeds.

\section{Antioxidant activity}

The most common methods to determine the antioxidant activity in a practical, rapid and sensitive manner are those that involve a radical chromophore, simulating the reactive oxygen species, and the free radical DPPH, of purple coloration that absorbs at $515 \mathrm{~nm}$, is one of the most widely used for in vitro evaluation of plant extracts and fractions (El Gengaihi et al., 2014). The results in Table 3 showed that, MSKE at a concentration of 100ppm, ethanol extract of mango seeds had the highest radical scavenging activity (96.86) at a concentration of 100ppm, followed by $\operatorname{BHT}(94.9 \%)$ and ascorbic $(91.53 \%)$. These results are higher than that obtained by (Mansour and Khalil 2000). This difference might be due to the interspecies variation.

The ferric reducing antioxidant power (FRAP) assay was used to evaluate the antioxidant capacities of the seeds extract. The FRAP assay is based on the capacity of antioxidants to reduce ferric (III) ions to ferrous (II) ions (Benzie and Szeto, 1999), The reducing power of the seeds extracts was measured by direct electron donation in the reduction of $[\mathrm{Fe}(\mathrm{CN}) 6]^{3-}$ to $[\mathrm{Fe}(\mathrm{CN}) 6]^{4-}$. The product was visualized by addition of free $\mathrm{Fe}^{3+}$ ions after the 
reduction reaction, by forming the intense Prussian blue color complex, $\quad\left(\mathrm{Fe}^{3+}\right)_{4}\left[\mathrm{Fe} 2+\left(\mathrm{CN}^{-}\right)_{6}\right]_{3}$, and quantified by absorbance measurement at $700 \mathrm{~nm}$ (Oyaizu, 1986). The FRAP value of the MSKE are shown in Table 3. The highest FRAP value was $4710 \mu$ mol $\mathrm{Fe}(\mathrm{II}) / \mathrm{g}$. The values of absorbance at $700 \mathrm{~nm}$ for the extracts of mango seeds kernel in Table 3 revealed that, MSKE had a high capacity to reduce iron (III). The reducing power (RP) of the MSKE was 0.85 . The extracts from the mango seed had RP values higher than BHA at 100 ppm. Wojdylo et al., (2007) reported that herbs can be classified into their antioxidant capacity as: very low FRAP $(<10$ $\mu \mathrm{M} / 100 \mathrm{~g})$, low FRAP (10-50 $\mu \mathrm{M} / 100 \mathrm{~g})$, good FRAP (50-100 $\mu \mathrm{M} / 100 \mathrm{~g})$, high FRAP $(100-500$ $\mu \mathrm{M} / 100 \mathrm{~g})$ and very high FRAP (>500 $\mu \mathrm{M} / 100 \mathrm{~g}$ ). According to this classification MSKE could be considered as a high antioxidant capacity.

\section{Identified content of the phenolic compounds}

HPLC is the preferred technique for both separation and quantification of phenolic compounds (Naczk and shahidi 2004). The HPLC analysis of the phenolic compounds in mango seeds extracts were compiled in Table 4. Results revealed that the alcoholic extract $(80 \%)$ of MSkE contained 20 identified phenolic compounds. The highest amount of phenolic compounds were Ellagic, Pyrogallol, Chlorogenic, Catachin, Mangiferin, Protocatechuic, Gallic, Cinnamic, Catechol and Myricetin (2613, 1337, 1182, 757, 516, 433, 349, 217, 202 and $106 \mathrm{mg} / 100 \mathrm{~g}$ ) on a dry wt basis, respectively. Puravankara et al., (2000), identified six phenolic compounds in mango seed extracts, mainly gallic acid, ellagic and gallates. The chromatogram corresponding for the ethanolic extract of mango seed showed that three compounds were found, of which one was identified, corresponding to gallic acid as the main component of the extract, in a concentration of $586.68 \mathrm{mg} / \mathrm{g} \mathrm{dw}$ (Vega-Vega et al., 2013). Yilmaz and Toledo (2004) concluded that aqueous solutions of ethanol, methanol mixture was better solvent than pure either of them as solvent system for the extraction of phenolics compound from 
Muscadine seed. Rodtjer et al., (2006) showed that the extraction yield of phenolic compounds is greatly dependent on the solvent polarity. The differences in composition presented between the extracts reported in the literature and in the present study may be due variety, degree of ripeness of the fruit used and the method of extraction. An important factor is the solvent used for the extraction of phenolic compounds, because solvents with different polarity extracted different compounds in varying quantities (Chen et al., 2011).

\section{Peroxide value (PV)}

Hydroperoxide is the primary oxidation product produced as result of lipid oxidation. It may break down into nonvolatile and volatile secondary products, which decrease the quality of the oil. This is an indicator of the initial stage of oxidative changes (Erwin $\boldsymbol{e t}$ al., 2004). The presence of hydroperoxide in the oil can be determined based on the oxidation of iodine ion with hydroperoxide. A saturated iodine solution added to the oil sample reacts with the produced hydroperoxide from the lipid oxidation and releases free iodine as the end product. The liberated iodine is then titrated against sodium thiosulphate. The titration value can be calculated and reported as peroxide value, mill equivalents of oxygen per kilogram oil sample (meq $\mathrm{O}_{2} / \mathrm{kg}$ ) (Shahidi and Wanasundara 1996). In this study, oxidation degree of sunflower oil samples were determined by measuring PV during accelerated oxidative storage of sunflower oil samples (with or without synthetic antioxidant or_natural mango seed extracts) at $70^{\circ} \mathrm{C}$ for $72 \mathrm{hr}$, as shown in Table 5. The results showed a continuous increase in PV with the increasing of storage times for all the samples. Initial rate increasw in PV was very slow, but it started to increase after $40 \mathrm{hr}$ of storage and went on increasing further with the increase in storage times $(72 \mathrm{hr})$. Peroxide values were in the range of 0.81 - 16.14 meq $\mathrm{O}_{2} / \mathrm{kg} \mathrm{SFO}$ for MSKE. SFO samples without antioxidant control (-ve) reached a maximum $\mathrm{PV}$ of 21.3 meq $\mathrm{O}_{2} / \mathrm{kg}$ SFO after $72 \mathrm{~h}$ of storage. The results in Table 5 showed significant differences in PV were observed between the control and 
SFO samples containing seeds extracts and synthetic antioxidants, which decreased the rate of peroxide formation. The PV of SFO sample containing 200 ppm of BHT was 17.62 meq $\mathrm{O}_{2} / \mathrm{kg}$, while $\mathrm{SFO}$ samples containing $(200,500,1000 \mathrm{ppm})$ MSKE were $16.14,14.95,13.25$ meq $\mathrm{O}_{2} / \mathrm{kg}$ SFO, respectively after72 $\mathrm{hr}$ at $70^{\circ} \mathrm{C}$. This data suggests the superiority of the antioxidant activity of MSKE at 200ppm over synthetic antioxidants. These results were in agreement with Abdalla et al.,(2007) who showed that ,increasing the levels of MSKE added to sunflower oil $(200,400$ and $800 \mathrm{pmm}$ ) led to a decrease in PV formed and retarding oxidatives rancidity during storage of sunflower oil at ambient temperature for 12 months. One can say that, the total antioxidant activity of by-product fruit seed extracts was linearity proportional to the concentration of total phenolic compounds. However, all oil samples with seed extract at 500 and 1000ppm were better than that of the synthetic antioxidants.

$P$-Anisidin value (P-anV)

During lipid oxidation, hydroperoxides, the primary reaction products, decompose to produce secondary oxidation products (aliphatic aldehydes, ketones, alcohols, acids and hydrocarbons) which are more stable during the storage time and an responsible for the off-flavors and off-odors of oxidized edible oils. In order to ensure a better monitoring of lipid oxidation process in the storage time, the simultaneous detection of primary and secondary lipid oxidation products is necessary. $\mathrm{p}$-anV is a reliable measurement of the amount of secondary oxidation products (Zhang et al.,2010; De Abreu et al.,2010). The added anisidine reacts with the aldehyde and produces a yellow colored solution. The yellow color is measured at the absorbance value of $350 \mathrm{~nm}$. A lower P-anV indicates a better quality of oil (Shahidi and Zhong 2005). Results in Table 6 presents the changes recorded in $\mathrm{p}$-anV during accelerated storage of SFO at $70^{\circ} \mathrm{C}$ for $72 \mathrm{hr}$, as effected by supplementation with BHT and different constitutions of MSKE. It can be observed that accelerated storage promoted rapid transformation to secondary products which contributes to the 
off-flavors of sunflower oil. Addition of BHT and various levels of MSKE resulted in significant decrease in $\mathrm{p}$-an $\mathrm{V}$ relative to the control sample. A gradual continuous increase in $\mathrm{p}$ anV with increasing storage times for all the samples was noticed. Initially the rate in $\mathrm{p}$-anV was very slow, but it started to increase after $44 \mathrm{hr}$ of storage and went on increasing further with increasing the storage times $(72 \mathrm{hr})$. All levels of MSKE provide good protection against secondary oxidation of SFO samples. The active compounds present in the fruit seeds extract might decompose with storage time. However, an increase in the extracts concentration could extend the period, which was evidenced in the results of this study. The $\mathrm{p}-\mathrm{anV}$ of the treated samples showed a similar trend with the reported PVs, as shown in Table 6. At the end of storage, there were no significant differences between supplemented SFO samples with BHT or MSKE $(200 \mathrm{mg} / \mathrm{kg})$. This means that MSKE at a level of $200 \mathrm{ppm}$ provide a protection effects equivalent to $200 \mathrm{ppm}$ of BHT against secondary lipid oxidation.
MSKE can be suggested as a potential source of antioxidants in the prevention of the production of secondary products in edible oils during storage. These data are in agreement with those reported by Iqbal and Bhanger, (2007); Yim et al., (2013) which highlight that the natural extracts showed a significant inhibitory effect against oxidation of refined oils.

\section{TOTOX Value}

This parameter gives a measurement value of the total oxidation, including primary and secondary oxidation products Hashemi et al., (2014). The total oxidation of the oil sample can be calculated based on the determined $\mathrm{PV}$ and $\mathrm{p}$-anV values (Nyam et al., 2013) are calculate TOTOX value according to the following equation: \{TOTOX value $=2 \mathrm{PV}+\mathrm{p}$-anV $\}$. These values reflect the initial and later stages of the oil oxidation. It measures the primary product, hydroperoxide, and its breakdown product, aldehyde. Therefore, it provides a better estimation of the progressive oxidative deterioration of the oil. The lower TOTOX value indicates a higher 
quality of the oil (O'Keefe and Pike 2010).

The TOTOX values of the supplemented sunflower oil samples are shown in Figur1. All the supplemented samples showed positive effects in inhibiting oxidative rancidity. As compared to the control, all the supplemented samples were observed to have lower TOTOX values. The TOTOX values of all the samples including synthetic antioxidants were as follow: control > 200ppm MSKE > 200ppm BHT > 500ppm MSKE> 1000ppm MSKE. The highest level of MSKE had the best inhibitory effect on oil oxidation in the storage time.

\section{Acid value (AV)}

The acid value of an oil or fat is defined as the number of milligrams of potassium hydroxide required to neutralize the free acidity in one gram of sample. The results are often expressed as the percentage of free fatty acids (FFA), especially in UK. The acid value is a measure of the extent to which the glycerides in the oil have been decomposed by lipase or other action. The decomposition is accelerated by heat and light (David, 1976). Free fatty acid and acid value of any lipid are measure of hydrolytic rancidity (Rehab, 2010). The results in Table 7 represent the effect of MSKE on acid values of SFO during accelerated storage at $70^{\circ} \mathrm{C}$ for $72 \mathrm{hr}$. The results showed that, a continuous increase in $\mathrm{AV}$ with increasing storage time $(72 \mathrm{hr})$ for all the samples, MSKE had pronounced antioxidant activity against hydrolytic oxidative rancidity of SFO samples during storage. The antioxidant activity of 1000 ppm MSKE was higher than $200,500 \mathrm{ppm}$ or $200 \mathrm{ppm}$ of BHT. The acid value in the samples with MSKE or BHT were lower than that in the control sample, indicating that these extract or BHT can retard SFO rancidity. The high amount of total phenolic compounds in MSKE may be responsible for decreased AVs in SFO samples during accelerated storage at $70^{\circ} \mathrm{C}$ for $72 \mathrm{hr}$. These results were in agreement with Jayaprakash et al., (2001) noted that phenolic compounds donate hydrogen atoms to scavenge and stabilize lipid radicals. Also, the results in agreement with Sikwese and 
Doudo (2007) who reported that the contribution of plant extracts to inhibit lipid oxidation due to their phenolic content. These results indicate that the MSKE have significant potential to be used as natural antioxidants to retard oil oxidation

\section{Thiobarbituric Acid Reactive} Substances value (TBARS)

TBARS values have been widely used as the marker for oxidative stress (Yim et al., 2013). The basic principle of the method is the reaction of one molecule of Malondialdehyde (MDA) and two molecules of thiobarbituric acid (TBA) to form a red MDA-TBA complex, which can be quantified spectro photometrically at $530 \mathrm{~nm}$. In many cases, the TBA test is recommended for comparing samples of a single material at different states of oxidation. Currently, it is known that TBARS assay is a general method for the detection of lipid peroxidation (Lee and Yoon 2013). MDA is a component of the fatty acids with three or more double bonds. It is produced following the degradation of polyunsaturated fatty acids during lipid oxidation. The primary product, hydroperoxide reacts with oxygen to form MDA, which contributes to the off-flavor of the oil (Zhang et al., 2010). The TBA values are expressed as milligrams of MDA equivalents per kilogram of sample (Zhang et al., 2010). Results in Table 8 presents the changes recorded in TBARS values of the supplemented sunflower oil samples during accelerated storage at $70^{\circ} \mathrm{C}$ for 72 $\mathrm{hr}$, as effected by supplementation with BHT, MSKE. The results show that MSKE were able to inhibit the formation of TBARS at all concentrations. The TBARS values of all the supplemented samples and the control increased gradually from zero time to 72 hours. As the concentration of seeds extracts increased, the amounts of secondary products detected were lower. This result was in accordance with the obtained P-anV. The secondary products were determined to be lower at higher concentrations of seeds extracts. Results in Table 8 showed that, significant differences in TBARS values were observed between the control and sunflower oil samples containing seeds extracts or synthetic antioxidants, which slowed the 
rate of lipid peroxidation. The TBARS value of SFO sample without antioxidants was 3.62 $\mathrm{mg} / \mathrm{kg}$, while the TBARS value of SFO sample containing $200 \mathrm{ppm}$ of BHT was $1.49 \mathrm{mg} / \mathrm{kg}$. TBARS values of SFO samples containing 200,500, 1000 ppm MSKE were $1.79, \quad 1.56$ and $1.42 \mathrm{mg} / \mathrm{kg}$ respectively, at $70^{\circ} \mathrm{C}$ for $72 \mathrm{hr}$. The inhibitory effect of the SFO samples at high concentration was stronger than that of BHT at 200ppm (1.49 mg/kg).

\section{CONCOLUSION:}

The highest level of MSKE (500, $1000 \mathrm{ppm})$ provides the best protection against primary and secondary oxidation of SFO samples during storage than synthetic antioxidant BHT. Showing that a high potential of mango seed kernel extract for use as sources of natural antioxidants.

\section{REFRANCES:}

Abdalla AEM; Darwish SM; Ayad EHE and ElHamahmy RM (2007):

Egyptian mango by -product 1: compositional quality of mango seed kernel. Food Chem 103:1134-1140

Antonio P; Alessandra DC and Giampaola C (2003):

From plums to prunes: Influence of drying parameters on polyphenols and antioxidant activity. Journal of Agricultural and Food Chemistry, 51, 36753681 .

AOAC (2005):

Official methods of analysis $\left(18^{\text {th }}\right.$ ed.). Association of Official Analytical Chemists, Washington, DC, USA.

\section{AOCS (1995):}

Official Methods and Recommended Practices of the American Oil Chemists' Society, 4th ed.; AOCS: Champaign, IL, USA,.

Benzie IFF and Szeto YT (1999):

Total antioxidant capacity of teas by the ferric reducing/antioxidant power assay. J. Agr. Food Chem., 47, 633-636. 
Chen YC; Lin JTS; Liu C; Lu PS and Yang DJ (2011):

"Composition of Flavonoids and Phenolic Acids in Lychee (Litchi chinensis Sonn.) Flower Extracts and Their Antioxidant Capacities Estimated with Human Ldl, Ery- throcyte, and Blood Models," Journal of Food Science, Vol. 76, No. 5 , pp. 724-728.

\section{David P (1976):}

The Chemical Analysis of Foods, 7th edn., Churchill. London

\section{De Abreu DAP; Losada PP; Maroto $J$ and Cruz JM (2010):}

Evaluation of the effectiveness of a new active packaging film containing natural antioxidants (from barley husks) that retard lipid damage in frozen Atlantic salmon (salmosalar L.) Food Res. Int., 43: 1277 $-1282$

Egyptian Standard (2013):

Vegetable edible oils. Edible sunflower oil. No 49 part 7.
Egyptian Organization for Standardization and Quality.

Einbond LS; Reynertson KA; Luo X-D; Basile MJ and Kennelly EJ (2004):

Anthocyanin antioxidants from edible fruits. Food Chemistry, 84, 23-28.

El Anany AM (2007):

Influence of pomegranate (Punica granatum) peel extract on the stability of sunflower oil during deepfat frying process. Electron. J. Food Plants Chem., 2, 14-19.

El Anany AM (2015):

Nutritional composition, anti-nutritional factors, bioactive compounds and antioxidant activity of guava seeds (PsidiumMytaceae) as affected by roasting processes. J.Food Sci Technol., 52(4):2175-2183.

El Gengaihi S; Aboul Ella FM; Emad MH; Shalaby E and Doha H (2014):

Antioxidant activity of phenolic compound from different grape wastes. $J$. Food Processing and 
Technology, Vol.5: 296 300

Erwin W; Anna G; Marzanna H; Henryk HJ; Jozef K; Maria M; Sylwia M; Magdalena R; Urszula S and Renata Z (2004):

Oxidation of lipids in food. Pol. J. Food Nutr. Sci., 13, 87-100.

Eva Dorta Mónica González; Gloria Lobo M; Concepción SánchezMoreno and Begoña de Ancos (2014):

Screening of phenolic compounds in by-product extracts from mangoes (Mangifera indica L.) by HPLC-ESI-QTOF-MS and multivariate analysis for use as a food ingredient. Food Research International (57 )51-60.

FAOSTAD (2015):

Food and Agriculture organization of the United Nations. FAO. Retrieved from http://faostat. Fao.org/site/339/default.asp $x$.
Fennema OR (1976):

Principles of food science, part 1. Marcel Dekker Inc: Food chemistry.

Gallegos-Infante JA; RochaGuzman NE; GonzalezLaredo RF and PulidoAlonso J (2010):

Effect of processing on the antioxidant properties of extracts from Mexican barley (Hordeum vulgare) cultivar. Food Chem 119:903-906.

Barzegar Goli $M$ and Sahari MA (2004):

Antioxidant activity and total phenolic compounds of pistachio (Pistachia vera) hull extracts. Food Chem 92: $521-525$

\section{Guo XD; Wu CS; Ma YJ; Parry}

$\mathrm{J}$; Xu YY; Liu $\mathrm{H}$ and Wang M (2012):

Comparison of milling fraction of tartary buckwheat for their phenolic and antioxidant properties. Food Research International 49: 53-59. 
Hashemi MB; Niakousari M; Saharkhiz MJ and Eskandari. MH (2014):

Stabilization of sunflower oil with Carum copticum Benth \& Hook essential oil. J. Food Sci Technol., 51: 142-147.

\section{Iqbal S and Bhanger MI (2007):}

Stabilization of sunflower oil by garlic extracts during accelerated storage. Food Chem., 100, 246-254.

\section{IUPAC (1987):}

Standard methods for the analysis of oils, fats, and derivatives (7th ed.) Oxford: Blackwell Scientific Publication.

Janas KM; Amarowicz R; Zielinska-Tomaszewska $\mathbf{J}$; Kosinska $A$ and Posmyk MM (2009):

Induction of phenolic compounds in two darkgrown lentil cultivars with different tolerance to copper ions . Acta Physiol Plant., 31: 587-595.
Jang HA; Kim YP and Kim HS (2012):

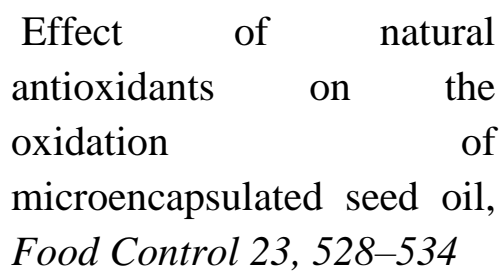

Jayaprakasha G; Singh $\mathbf{R}$ and Sakariah K (2001):

Antioxidant activity of grape seed (Vitis vinifera) extracts on peroxidation models in vitro. Food Chemistry, 37, 285-290

Jayaprakasha GJ; Selvi T and Sakariah KK (2003):

Antibacterial and antioxidant activities of grape (Vitis vinifera) seed extracts. Food Research International 36: 117-122.

Jung CH; Seog HM; Choi IW; Park MW and Cho HY (2006):

Antioxidant properties of various solvent extracts from wild ginseng leaves. LWT-food Sci. Technol.,39: $266-274$.

Lee YJ and Yoon WB ( 2013 ): 
Effects of particle size and heating time on thiobarbituric acid (TBA) test of soybean powder. Food Chem. 138: 841-850.

\section{Mansour EH and Khalil AH} (2000):

Evaluation of Antioxi-dant Activity of Some Plant Extracts and their Application to Ground Beef Patties. Food Chemistry, Vol. 69(2), pp.135-141.

\section{Mariana-AtenaPoiana (2012):}

Enhancing Oxidative Stability of Sunflower Oil during Convective and Microwave Heating Using Grape Seed Extract. Int. J. Mol. Sci. 2012, 13, 92409259.

\section{Mohdaly AAA; Sarhan MA and} Mahmoud A (2010):

Antioxidant efficacy of potato peels and sugar beet pulp extracts in vegetable oils protection. Food Chem., 123, 1019-1026.

\section{Monagas M; Garrido I; Lebron- Aguilar R; Gomez- Cordoves MC; Rybarczyk}

A; Amarowicz $\mathbf{R}$ and Bartolome B (2009):

Comparative flavan-3-ol profile and antioxidant capacity of roasted peanut, hazelnut, and almond skins. J Agric Food Chem 57:10590-10599

Naczk $M$ and Shahidi F (2004):

Review: Extraction and analysis of phenolics in food. J. Chromatograph 1054: 95-111.

\section{Nyam KL; Wong MM; Long K and Tan CP (2013):}

Oxidative stability of sunflower oils supplemented with kenaf seeds extract, roselle seeds extract and roselle extract, respectively under accelerated storage. Int. Food Res. J., 20, 695701 .

O'Keefe SF and Pike OA (2010):

Fat Characterization. In Food Analysis, 4th ed.; Nielsen, S.S., Ed.; Springer Science and Business Media: New York, NY, USA,; pp. 239-260.

Oyaizu M (1986): 
Studies on products of the browning reaction, Antioxidative activities of browning reaction products prepared from glucosamine. Eiyogaku Zasshi, 44, 307315 .

\section{Pitchaon M (2011):}

Antioxidant capacity of extracts and fractions from mango (mangiferaindica Linn.) seed kernels, International Food Research Journal, 18:523 - 528.

Puravankara D; Bohgra V and Sharma R S (2000):

Effect of antioxidant principles isolated from mango (Mangifera indica L.) seed kernels on oxidative stability of buffalo ghee (butter-fat). Journal of the Science of Food and Agriculture, 80(4), 522-526.

\section{Rakic S; Povrenovic D; Tesevic} V; Simic $M$ and Maletic $R$ (2006):

Oak acorn, polyphenols and antioxidant activity in functional food, J. Food Eng $74: 416-423$
Rehab FMA (2010):

Improvement the stability of fried sunflower oil by using different levels of Pomposia (Syzyyium cumini), Electronic Journal of Environmental, Agricultural and Food Chemistry 9(2):396-403.

Rodtjer A; Skibsted LH and Andersen M (2006):

Antioxidative and prooxidative effect of extracts made from cherry liqueur pomace. Food Chem 99: 6-14.

Saad B; Yong YS; Mohd AN; Noorhasani H; Abdussalam SMA; Muhammad IS; Saida FS; Khariuddin MT and Kamarudzaman A (2007):

Determination of synthetic phenolic antioxidants in food items using reversedphase HPLC. Food Chem. 105, 389-394.

\section{Shahidi F and Wanasundara UN (1996): \\ Methods for evaluation of oxidative stability of lipid- containing foods,}


Food Sci. Technol. Int., 2, $73-81$.

Shahidi F and Zhong Y (2005):

Lipid

Oxidation:

Measurement Methods.

Bailey's Industrial Oil and

Fat Products, 6th ed.; John

Wiley \& Sons, Inc.:

Hoboken, NJ, USA,; pp. 357-385.

Sikwese FE and Duodu KG (2007):

Antioxidant effect of a crude phenolic extract from sorghum bran in sunflower oil in the presence of ferric ions, Food Chemistry 104: 324-331.

Singleton VL and Rossi JA (1965):

Colorimetry of total phenolics with phosphomolybdic phosphotungstic acid reagents, American Journal of Enology and Viticulture, 16, 144-158

Soong YY and Barlow PJ (2004):

Antioxidant activity and phenolic content of selected fruit seeds. Food Chemistry, 88(3), 411-417.

Sung J and Lee J (2010):

Antioxidant and antiproliferative of grape seeds from different cultivars, Food Science Biotechnology 19 (2): 321326.

Vega-Vega V; Silva-Espinoza BA; Cruz-Valenzuela MR; Bernal Mercado AT; González-Aguilar GA; Ruíz-Cruz S; Moctezuma E; Siddiqui MD W and Ayala- Youssef AMM (1999):

Utilization of the seed of mango processing wastes as a secondary source of oil and protein, Alexandria Journal of Agricultural Research, 44(3), 149-166

Wojdyło JF; Oszmiański A J and Czemerys R (2007):

Antioxidant activity and phenolic compounds in 32 selected herbs. Journal of Food chemistry105: 940 94. 
Yanagimoto K; Lee K; Ochi H and Shibamoto T (2002):

Antioxidative activity of hetero- cyclic compounds found in coffee volatiles produced by the Maillard reaction, J. Agric Food Chem 50:5480-5484

\section{Yang J; Martinson TE and Liu} RH (2009):

Photochemical profiles and antioxidant activities of wine grapes, Food Chem. 116, 332-339.

Yanishlieva NV and Marinova EM (2001):

Stabilization of edible oils with natural antioxidants. European Journal of Lipid Science and Technology, 103 ,

\section{Yilmaz Y and Toledo RT (2004):}

Major flavonoids in grape seeds and skins antioxidant capacity of catechin, epicatechin and gallic acid. $J$ Agric Food Chem 52: 255260.

Yim HS; Chye FY; Liow ML and Ho CW (2013):
Antioxidant potential of Pleurotus porrigens Extract and application in sunflower oil during accelerated storage, Chiang Mai J. Sci., 40, 34-48.r3

Youssef AMM (1999):

Utilization of the seed of mango processing wastes as a secondary source of oil and protein, Alexandria Journal of Agricultural Research, 44(3), 149-166

\section{Zhang Y; Yang L; Zu Y; Chen} $X$; Wang $F$ and Liu $F$ (2010):

Oxidative stability of sunflower oil supplemented with carnosic acid compared with synthetic antioxidants during aceelerated storage. Food Chem., 118, 656-662.

Zhishen H, Mengcheng $\mathbf{T}$ and
Jianmin W (1999):
The determination of
flavonoid contents in
mulberry and their
scavenging effects on
superoxide radicals. Food
Chem; 64:555-559.


Table 1: Proximate composition of Mango seeds powder (g\100g) *

\begin{tabular}{|l|c|c|c|c|c|c|}
\hline Nutrients & $\begin{array}{c}\text { Moisture } \\
\text { Mean } \pm \\
\text { SD }\end{array}$ & $\begin{array}{c}\text { Protein } \\
\text { Mean } \pm \\
\text { SD }\end{array}$ & $\begin{array}{c}\text { Fat } \\
\text { Mean } \\
\pm \text { SD }\end{array}$ & $\begin{array}{c}\text { Fiber } \\
\text { Mean } \\
\pm \text { SD }\end{array}$ & $\begin{array}{c}\text { Carbohydrate } \\
\text { Mean } \pm \text { SD }\end{array}$ & $\begin{array}{c}\text { Ash } \\
\text { Mean } \\
\pm \text { SD }\end{array}$ \\
\hline g / 100 g & $8.1 \pm 0.3$ & $6.9 \pm$ & $12.5 \pm$ & $2.9 \pm$ & $67.3 \pm 2$ & $2.3 \pm$ \\
& & 0.25 & 0.45 & 0.2 & & 0.2 \\
\hline
\end{tabular}

* Data obtained from at least three replicates.

Table 2: Yield, total phenolic compounds and total flavonoids content of mango seeds kernel *

\begin{tabular}{|l|c|}
\hline Samples & Mango seed \\
\hline Yield \% (g/100 g) & $9.43 \pm 0.64$ \\
\hline Total phenolics (mg gallic/ g dw) & $21.29 \pm 0.85$ \\
\hline $\begin{array}{l}\text { Total flavanols (mg catechin / g } \\
\text { dw) }\end{array}$ & $22.20 \pm 0.66$ \\
\hline
\end{tabular}

* Data obtained from at least three replicates.

Table 3: Antioxidant activity of MSKE compared with BHT*

\begin{tabular}{|l|l|l|l|}
\hline parameters & \multicolumn{1}{|c|}{$\begin{array}{c}\text { Mango seed } \\
\text { kernel }\end{array}$} & BHT & $\begin{array}{c}\text { Ascorbic } \\
\text { acid }\end{array}$ \\
\hline $\begin{array}{l}\text { DPPH Inhibition \% } \\
(\mathbf{1 0 0} \boldsymbol{\mu l} / \mathbf{m l}) \mathbf{1 0 0 p p m}\end{array}$ & $96.86 \pm 3.2^{\mathrm{a}}$ & $94.9 \pm 2.7^{\mathrm{a}}$ & $91.53 \pm 3.3^{\mathrm{b}}$ \\
\hline $\begin{array}{l}\text { FRAP value(}(\boldsymbol{\mu m o l} \mathbf{B H T} \\
\left.\text { equivalent } \mathbf{~}^{\mathbf{1}}\right)\end{array}$ & $4710.33 \pm 142^{\mathrm{a}}$ & - & - \\
\hline $\begin{array}{l}\text { Reducing } \\
\text { power(mg/ml) } \\
(\mathbf{a b s o r b a n c e} \text { at } \mathbf{7 0 0} \mathbf{~ n m})\end{array}$ & $0.85 \pm 0.02^{\mathrm{a}}$ & $0.36 \pm 0.03^{\mathrm{b}}$ & - \\
\hline
\end{tabular}

*Means in a row followed by the same letter are not significantly different at $<0.05$. Data obtained from at least three replicates. 
Table 4: yield of identified phenolic compounds ( $\mathrm{mg} / 100 \mathrm{~g} \mathrm{dr}$ matter) in mango seeds extract as determined by HPLC

\begin{tabular}{|l|l|c|}
\hline No & \multicolumn{1}{|c|}{$\begin{array}{c}\text { phenolic } \\
\text { compounds }\end{array}$} & $\begin{array}{c}\text { (mg/100g dry } \\
\text { extract) }\end{array}$ \\
\hline $\mathbf{1}$ & Gallic & 349.66 \\
\hline $\mathbf{2}$ & Pyrogllol & 1337.66 \\
\hline $\mathbf{3}$ & Chlorogenic & 1182 \\
\hline $\mathbf{4}$ & Protocatechuic & 433.65 \\
\hline $\mathbf{5}$ & Catechol & 202 \\
\hline $\mathbf{6}$ & Caffeic & 7.1 \\
\hline $\mathbf{7}$ & Vanillic & 21.6 \\
\hline $\mathbf{8}$ & Catechin & 757 \\
\hline $\mathbf{9}$ & Caffeine & 12.56 \\
\hline $\mathbf{1 0}$ & Ellagic & 2613 \\
\hline $\mathbf{1 1}$ & Coumaric & 12.9 \\
\hline $\mathbf{1 2}$ & Mangiferin & 516 \\
\hline $\mathbf{1 3}$ & Sinapic acid & 17.63 \\
\hline $\mathbf{1 4}$ & Ferulic acid & 32.06 \\
\hline $\mathbf{1 5}$ & Salicylic & 78.66 \\
\hline $\mathbf{1 6}$ & Kaempferol & 4 \\
\hline $\mathbf{1 7}$ & Cinnamic & 217 \\
\hline $\mathbf{1 8}$ & Quercetin & 39.3 \\
\hline $\mathbf{1 9}$ & Myricetin & 106.3 \\
\hline $\mathbf{2 0}$ & tannins & 21.6 \\
\hline & & \\
\hline
\end{tabular}


Evaluation of Mango Seed kernel Extract as natural occurring phenolic rich antioxidant compound

Talaat M.A El-Kady; Mohamed K Abd El-Rahman; Toliba AO and Samy M Abo El-maty

Table (5): Effect of MSKE at different concentration on PV * $\left(\mathrm{meq} . \mathrm{O}_{2} / \mathrm{Kg} \mathrm{SFO}\right)$ during accelerated storage at $70^{\circ}$ for $72 \mathrm{~h}$

\begin{tabular}{|c|c|c|c|c|c|}
\hline \multirow{2}{*}{$\begin{array}{c}\text { Tim } \\
\text { e } \\
\text { (hr) }\end{array}$} & \multirow[t]{2}{*}{ Control } & \multirow{2}{*}{$\begin{array}{c}\text { BHT } \\
200 \mathrm{ppm}\end{array}$} & \multicolumn{3}{|c|}{ MSKE } \\
\hline & & & 200ppm & 500 ppm & 1000 ppm \\
\hline $\mathbf{0}$ & $0.81 \pm 0.01^{\mathrm{a}}$ & $0.81 \pm 0.02^{\mathrm{a}}$ & $0.81 \pm 0.02^{\mathrm{a}}$ & $0.81 \pm 0.03^{\mathrm{a}}$ & $0.81 \pm 0.02^{\mathrm{a}}$ \\
\hline 4 & $2.10 \pm 0.04^{\mathrm{a}}$ & $1.89 \pm 0.05^{\mathrm{b}}$ & $1.83 \pm 0.03^{\mathrm{bc}}$ & $1.81 \pm 0.03^{\mathrm{c}}$ & $1.40 \pm 0.04^{\mathrm{c}}$ \\
\hline 8 & $3.21 \pm 0.06^{\mathrm{a}}$ & $2.63 \pm 0.04^{b}$ & $2.47 \pm 0.04^{\mathrm{c}}$ & $2.25 \pm 0.04^{\mathrm{d}}$ & $2.07 \pm 0.07^{\mathrm{e}}$ \\
\hline 12 & $4.44 \pm 0.05^{\mathrm{a}}$ & $3.59 \pm 0.05^{\mathrm{c}}$ & $4.24 \pm 0.04^{b}$ & $3.55 \pm 0.05^{\mathrm{c}}$ & $3.54 \pm 0.05^{\mathrm{c}}$ \\
\hline 16 & $5.66 \pm 0.04^{\mathrm{a}}$ & $4.13 \pm 0.05^{c}$ & $4.48 \pm 0.03^{b}$ & $3.90 \pm 0.04^{\mathrm{d}}$ & $3.67 \pm 0.04^{\mathrm{e}}$ \\
\hline 20 & $6.12 \pm 0.05^{\mathrm{a}}$ & $4.47 \pm 0.04^{b}$ & $4.50 \pm 0.05^{b}$ & $4.37 \pm 0.04^{\mathrm{c}}$ & $4.16 \pm 0.05^{d}$ \\
\hline 24 & $7.29 \pm 0.05^{\mathrm{a}}$ & $5.45 \pm 0.05^{b}$ & $4.77 \pm 0.04^{c}$ & $4.65 \pm 0.03^{c}$ & $4.45 \pm 0.04^{\mathrm{d}}$ \\
\hline 28 & $8.12 \pm 0.04^{\mathrm{a}}$ & $5.66 \pm 0.04^{b}$ & $4.92 \pm 0.05^{\mathrm{c}}$ & $4.72 \pm 0.04^{\mathrm{d}}$ & $4.69 \pm 0.04^{\mathrm{d}}$ \\
\hline 32 & $8.36 \pm 0.05^{\mathrm{a}}$ & $6.36 \pm 0.03^{b}$ & $5.14 \pm 0.04^{c}$ & $4.91 \pm 0.05^{\mathrm{d}}$ & $4.78 \pm 0.04^{\mathrm{d}}$ \\
\hline 36 & $9.11 \pm 0.06^{\mathrm{a}}$ & $6.52 \pm 0.04^{b}$ & $5.89 \pm 0.05^{\mathrm{c}}$ & $5.39 \pm 0.08^{d}$ & $5.55 \pm 0.05^{\mathrm{e}}$ \\
\hline 40 & $9.62 \pm 0.04^{\mathrm{a}}$ & $7.22 \pm 0.05^{b}$ & $6.65 \pm 0.07^{\mathrm{c}}$ & $5.10 \pm 0.06^{\mathrm{d}}$ & $5.39 \pm 0.04^{\mathrm{e}}$ \\
\hline 44 & $10.43 \pm 0.05^{\mathrm{a}}$ & $8.31 \pm 0.06^{b}$ & $6.63 \pm 0.05^{c}$ & $6.43 \pm 0.06^{\mathrm{d}}$ & $6.23 \pm 0.08^{\mathrm{e}}$ \\
\hline 48 & $12.36 \pm 0.06^{\mathrm{a}}$ & $9.17 \pm 0.06^{b}$ & $8.14 \pm 0.05^{\mathrm{c}}$ & $7.12 \pm 0.10^{d}$ & $6.85 \pm 0.05^{\mathrm{e}}$ \\
\hline 52 & $13.62 \pm 0.05^{\mathrm{a}}$ & $10.44 \pm 0.07^{b}$ & $8.94 \pm 0.07^{b}$ & $8.26 \pm 0.08^{c}$ & $7.22 \pm 0.03^{d}$ \\
\hline 56 & $14.94 \pm 0.08^{\mathrm{a}}$ & $11.75 \pm 0.06^{\mathrm{c}}$ & $10.49 \pm 0.08^{b}$ & $9.13 \pm 0.07^{\mathrm{d}}$ & $8.22 \pm 0.09^{\mathrm{e}}$ \\
\hline 60 & $15.35 \pm 0.06^{\mathrm{a}}$ & $12.98 \pm 0.11^{\mathrm{c}}$ & $13.41 \pm 0.08^{b}$ & $10.24 \pm 0.05^{\mathrm{d}}$ & $9.07 \pm 0.08^{\mathrm{e}}$ \\
\hline 64 & $16.88 \pm 0.06^{\mathrm{a}}$ & $13.42 \pm 0.12^{b}$ & $14.87 \pm 0.11^{\mathrm{c}}$ & $12.67 \pm 0.07^{\mathrm{d}}$ & $10.92 \pm 0.1^{\mathrm{e}}$ \\
\hline 68 & $18.09 \pm 0.05^{\mathrm{a}}$ & $14.83 \pm 0.13^{b}$ & $15.64 \pm 0.09^{c}$ & $13.76 \pm 0.10^{\mathrm{d}}$ & $12.11 \pm 0.1^{\mathrm{e}}$ \\
\hline 72 & $21.30 \pm 0.06^{\mathrm{a}}$ & $16.62 \pm 0.17^{b}$ & $16.14 \pm 0.06^{\mathrm{c}}$ & $14.95 \pm 0.15^{\mathrm{d}}$ & $13.25 \pm 0.13^{\mathrm{e}}$ \\
\hline
\end{tabular}

Means in a row followed by the same letter are not significantly different at $<0.05$.

Data obtained from at least three replicates.

* According to Egyptian standard (2013) PV of SFO should be less than 10 meq $. \mathrm{O}_{2} / \mathrm{Kg} \mathrm{SFO}$. 
TABLE (6): Effect of MSKE at different concentration on p-Anisidine values of SFO during accelerated storage at $70^{\circ} \mathrm{C}$ for $72 \mathrm{~h}$

\begin{tabular}{|c|c|c|c|c|c|}
\hline \multirow{2}{*}{$\begin{array}{l}\text { Tim } \\
\text { e } \\
\text { (hr) }\end{array}$} & \multirow[t]{2}{*}{ Control } & \multirow{2}{*}{$\begin{array}{c}\text { BHT } \\
200 \mathrm{ppm}\end{array}$} & \multicolumn{3}{|c|}{ MSKE } \\
\hline & & & 200ppm & 500 ppm & $1000 \mathrm{ppm}$ \\
\hline $\mathbf{0}$ & $0.55 \pm 0.02^{\mathrm{a}}$ & $0.55 \pm 0.02^{\mathrm{a}}$ & $0.55 \pm 0.03^{\mathrm{a}}$ & $0.53 \pm 0.04^{\mathrm{a}}$ & $0.53 \pm 0.03^{\mathrm{a}}$ \\
\hline 4 & $2.15 \pm 0.05^{\mathrm{a}}$ & $1.21 \pm 0.04^{\mathrm{cd}}$ & $1.38 \pm 0.03^{b}$ & $1.29 \pm 0.06^{b c}$ & $1.16 \pm 0.06^{d}$ \\
\hline 8 & $3.85 \pm 0.04^{\mathrm{a}}$ & $2.28 \pm 0.08^{b}$ & $2.36 \pm 0.07^{b}$ & $2.30 \pm 0.09^{b}$ & $2.22 \pm 0.14^{b}$ \\
\hline 12 & $4.03 \pm 0.05^{\mathrm{a}}$ & $2.48 \pm 0.07^{\mathrm{cd}}$ & $2.65 \pm 0.04^{b}$ & $2.53 \pm 0.03^{c}$ & $2.35 \pm 0.04^{d}$ \\
\hline 16 & $4.34 \pm 0.08^{\mathrm{a}}$ & $2.74 \pm 0.08^{\mathrm{d}}$ & $2.93 \pm 0.07^{b c}$ & $2.81 \pm 0.06^{\mathrm{cd}}$ & $2.65 \pm 0.05^{\mathrm{e}}$ \\
\hline 20 & $4.71 \pm 0.08^{\mathrm{a}}$ & $2.98 \pm 0.10^{\text {de }}$ & $3.15 \pm 0.09^{b c}$ & $3.05 \pm 0.05^{\mathrm{cd}}$ & $2.89 \pm 0.07^{\mathrm{e}}$ \\
\hline 24 & $5.11 \pm 0.10^{\mathrm{a}}$ & $3.19 \pm 0.10^{\text {de }}$ & $3.34 \pm 0.05^{b c}$ & $3.26 \pm 0.09^{\text {cd }}$ & $3.11 \pm 0.03^{\mathrm{e}}$ \\
\hline 28 & $5.79 \pm 0.09^{\mathrm{a}}$ & $3.56 \pm 0.09^{d}$ & $3.72 \pm 0.04^{b c}$ & $3.69 \pm 0.06^{\mathrm{cd}}$ & $3.46 \pm 0.05^{e}$ \\
\hline 32 & $6.24 \pm 0.07^{\mathrm{a}}$ & $3.99 \pm 0.06^{\mathrm{c}}$ & $4.13 \pm 0.03^{b}$ & $4.02 \pm 0.04^{\mathrm{c}}$ & $3.88 \pm 0.04^{d}$ \\
\hline 36 & $6.85 \pm 0.06^{\mathrm{a}}$ & $4.38 \pm 0.07^{\mathrm{de}}$ & $4.59 \pm 0.08^{b c}$ & $4.46 \pm 0.06^{\mathrm{cd}}$ & $4.31 \pm 0.04^{\mathrm{e}}$ \\
\hline 40 & $7.48 \pm 0.05^{\mathrm{a}}$ & $4.89 \pm 0.07^{\mathrm{d}}$ & $5.01 \pm 0.06^{b}$ & $4.90 \pm 0.05^{\mathrm{cd}}$ & $4.76 \pm 0.06^{\mathrm{e}}$ \\
\hline 44 & $8.09 \pm 0.07^{\mathrm{a}}$ & $5.29 \pm 0.05^{\mathrm{d}}$ & $5.56 \pm 0.05^{b}$ & $5.37 \pm 0.05^{c}$ & $5.22 \pm 0.06^{\mathrm{e}}$ \\
\hline 48 & $9.24 \pm 0.04^{\mathrm{a}}$ & $5.84 \pm 0.05^{\mathrm{d}}$ & $6.08 \pm 0.05^{b}$ & $5.94 \pm 0.04^{c}$ & $5.77 \pm 0.05^{\mathrm{e}}$ \\
\hline 52 & $10.62 \pm 0.07^{\mathrm{a}}$ & $6.56 \pm 0.06^{\mathrm{de}}$ & $6.81 \pm 0.06^{b}$ & $6.62 \pm 0.06^{\mathrm{cd}}$ & $6.49 \pm 0.07^{\mathrm{e}}$ \\
\hline 56 & $11.84 \pm 0.04^{\mathrm{a}}$ & $7.12 \pm 0.06^{\mathrm{d}}$ & $7.39 \pm 0.07^{b}$ & $7.20 \pm 0.05^{\mathrm{c}}$ & $7.07 \pm 0.06^{d}$ \\
\hline 60 & $12.46 \pm 0.07^{\mathrm{a}}$ & $7.42 \pm 0.05^{\mathrm{d}}$ & $7.65 \pm 0.05^{b}$ & $7.48 \pm 0.04^{c}$ & $7.31 \pm 0.05^{\mathrm{e}}$ \\
\hline 64 & $13.13 \pm 0.07^{\mathrm{a}}$ & $7.82 \pm 0.04^{b}$ & $7.85 \pm 0.03^{b}$ & $7.71 \pm 0.04^{c}$ & $7.53 \pm 0.05^{d}$ \\
\hline 68 & $13.98 \pm 0.06^{\mathrm{a}}$ & $8.34 \pm 0.04^{b}$ & $8.37 \pm 0.04^{b}$ & $8.27 \pm 0.06^{c}$ & $8.19 \pm 0.06^{d}$ \\
\hline 72 & $14.88 \pm 0.05^{\mathrm{a}}$ & $8.98 \pm 0.04^{b}$ & $9.02 \pm 0.04^{b}$ & $8.91 \pm 0.05^{c}$ & $8.86 \pm 0.05^{c}$ \\
\hline
\end{tabular}

Means in a row followed by the same letter are not significantly different at $<0.05$.

Data obtained from at least three replicates. 
TABLE (7): Effect of MSKE at different concentration on acid values * (AV) of SFO during accelerated storage at $70^{\circ} \mathrm{C}$ for $72 \mathrm{~h}$

\begin{tabular}{|c|c|c|c|c|c|}
\hline \multirow{2}{*}{$\begin{array}{l}\text { Time } \\
(\mathrm{hr})\end{array}$} & \multirow[t]{2}{*}{ Control } & \multirow{2}{*}{$\begin{array}{c}\text { BHT } \\
200 \mathrm{ppm}\end{array}$} & \multicolumn{3}{|c|}{ MSKE } \\
\hline & & & 200ppm & 500 ppm & 1000 ppm \\
\hline $\mathbf{0}$ & $0.09 \pm 0.01^{\mathrm{a}}$ & $0.09 \pm 0.01^{\mathrm{a}}$ & $0.09 \pm 0.01^{\mathrm{a}}$ & $0.09 \pm 0.01^{\mathrm{a}}$ & $0.09 \pm 0.01^{\mathrm{a}}$ \\
\hline 4 & $0.15 \pm 0.02^{a}$ & $0.11 \pm 0.01^{b c}$ & $0.12 \pm 0.01^{b}$ & $0.10 \pm 0.01^{\mathrm{c}}$ & $0.09 \pm 0.01^{\mathrm{c}}$ \\
\hline 8 & $0.19 \pm 0.03^{a}$ & $0.14 \pm 0.02^{b c}$ & $0.15 \pm 0.01^{b}$ & $0.13 \pm 0.01^{\mathrm{c}}$ & $0.10 \pm 0.01^{d}$ \\
\hline 12 & $0.26 \pm 0.02^{a}$ & $0.17 \pm 0.02^{\text {bce }}$ & $0.17 \pm 0.01^{b c}$ & $0.16 \pm 0.02^{\mathrm{ce}}$ & $0.13 \pm 0.02^{\mathrm{e}}$ \\
\hline 16 & $0.31 \pm 0.03^{a}$ & $0.21 \pm 0.01^{b}$ & $0.21 \pm 0.02^{b}$ & $0.20 \pm 0.01^{b}$ & $0.16 \pm 0.01^{\mathrm{c}}$ \\
\hline 20 & $0.37 \pm 0.03^{a}$ & $0.29 \pm 0.02^{b}$ & $0.28 \pm 0.02^{\mathrm{bc}}$ & $0.24 \pm 0.02^{c}$ & $0.19 \pm 0.03^{\mathrm{c}}$ \\
\hline 24 & $0.41 \pm 0.02^{a}$ & $0.34 \pm 0.01^{b}$ & $0.33 \pm 0.02^{b c}$ & $0.31 \pm 0.01^{\mathrm{c}}$ & $0.25 \pm 0.03^{d}$ \\
\hline 28 & $0.46 \pm 0.03^{a}$ & $0.38 \pm 0.02^{b}$ & $0.37 \pm 0.02^{b c}$ & $0.34 \pm 0.02^{\text {ce }}$ & $0.29 \pm 0.03^{\mathrm{e}}$ \\
\hline 32 & $0.49 \pm 0.02^{a}$ & $0.41 \pm 0.03^{b}$ & $0.43 \pm 0.02^{b}$ & $0.37 \pm 0.02^{\mathrm{c}}$ & $0.33 \pm 0.01 d$ \\
\hline 36 & $0.53 \pm 0.03^{a}$ & $0.45 \pm 0.03^{b}$ & $0.46 \pm 0.03^{b}$ & $0.41 \pm 0.02^{\mathrm{c}}$ & $0.37 \pm 0.01 d$ \\
\hline 40 & $0.57 \pm 0.03^{a}$ & $0.48 \pm 0.03^{b}$ & $0.47 \pm 0.03^{b c}$ & $0.44 \pm 0.02^{\mathrm{cd}}$ & $0.40 \pm 0.03^{\mathrm{d}}$ \\
\hline 44 & $0.61 \pm 0.02^{a}$ & $0.51 \pm 0.03^{b}$ & $0.50 \pm 0.03^{b}$ & $0.49 \pm 0.02^{b c}$ & $0.44 \pm 0.03^{\mathrm{c}}$ \\
\hline 48 & $0.68 \pm 0.02^{a}$ & $0.54 \pm 0.03^{b}$ & $0.53 \pm 0.03^{b}$ & $0.51 \pm 0.02^{b c}$ & $0.46 \pm 0.03^{\mathrm{c}}$ \\
\hline 52 & $0.77 \pm 0.05^{\mathrm{a}}$ & $0.57 \pm 0.03^{b c}$ & $0.59 \pm 0.02^{b}$ & $0.54 \pm 0.03^{\mathrm{cd}}$ & $0.51 \pm 0.03^{\mathrm{d}}$ \\
\hline 56 & $0.89 \pm 0.03^{a}$ & $0.61 \pm 0.03^{b c}$ & $0.64 \pm 0.03^{b}$ & $0.57 \pm 0.02^{\text {cd }}$ & $0.54 \pm 0.03^{d}$ \\
\hline 60 & $0.94 \pm 0.04^{\mathrm{a}}$ & $0.65 \pm 0.04^{b c}$ & $0.69 \pm 0.02^{b}$ & $0.63 \pm 0.03^{\mathrm{cd}}$ & $0.57 \pm 0.03^{\mathrm{d}}$ \\
\hline 64 & $1.07 \pm 0.05^{\mathrm{a}}$ & $0.70 \pm 0.03^{b}$ & $0.73 \pm 0.03^{b}$ & $0.70 \pm 0.03^{b}$ & $0.61 \pm 0.04^{\mathrm{c}}$ \\
\hline 68 & $1.15 \pm 0.04^{\mathrm{a}}$ & $0.74 \pm 0.04^{b}$ & $0.78 \pm 0.03^{b}$ & $0.75 \pm 0.03^{b}$ & $0.68 \pm 0.03^{\mathrm{c}}$ \\
\hline 72 & $1.28 \pm 0.04^{\mathrm{a}}$ & $0.79 \pm 0.03^{\mathrm{c}}$ & $0.91 \pm 0.03^{b}$ & $0.89 \pm 0.02^{b}$ & $0.76 \pm 0.02^{c}$ \\
\hline
\end{tabular}

Means in a row followed by the same letter are not significantly different at $<0.05$.

Data obtained from at least three replicates.

* According to Egyptian standard (2013) AV of SFO should be less than0.6 mg $\mathrm{KOH} / \mathrm{Kg} \mathrm{SFO}$. 
Evaluation of Mango Seed kernel Extract as natural occurring phenolic rich antioxidant compound

Talaat M.A El-Kady; Mohamed K Abd El-Rahman; Toliba AO and Samy M Abo El-maty

TABLE (8): Effect of MSKE at different concentration on TBARS of SFO during accelerated storage at $70^{\circ} \mathrm{C}$ for $72 \mathrm{~h}$

\begin{tabular}{|r|c|c|c|c|c|}
\hline \multirow{2}{*}{$\begin{array}{r}\text { Time } \\
\text { (hr) }\end{array}$} & Control & BHT & \multicolumn{3}{|c|}{ MSKE } \\
\cline { 4 - 6 } & & 200 ppm & $\mathbf{2 0 0 p p m}$ & $\mathbf{5 0 0} \mathbf{~ p p m}$ & $\mathbf{1 0 0 0} \mathbf{~ p p m}$ \\
\hline $\mathbf{0}$ & $0.08 \pm 0.01^{\mathrm{a}}$ & $0.08 \pm 0.01^{\mathrm{a}}$ & $0.08 \pm 0.01^{\mathrm{a}}$ & $0.08 \pm 0.01^{\mathrm{a}}$ & $0.08 \pm 0.01^{\mathrm{a}}$ \\
\hline $\mathbf{1 2}$ & $0.41 \pm 0.02^{\mathrm{a}}$ & $0.17 \pm 0.01^{\mathrm{d}}$ & $0.29 \pm 0.02^{\mathrm{b}}$ & $0.21 \pm 0.02^{\mathrm{c}}$ & $0.13 \pm 0.02^{\mathrm{e}}$ \\
\hline $\mathbf{2 4}$ & $0.68 \pm 0.02^{\mathrm{a}}$ & $0.31 \pm 0.01^{\mathrm{d}}$ & $0.47 \pm 0.02^{\mathrm{b}}$ & $0.34 \pm 0.01^{\mathrm{c}}$ & $0.23 \pm 0.02^{\mathrm{e}}$ \\
\hline $\mathbf{3 6}$ & $1.42 \pm 0.03^{\mathrm{a}}$ & $0.42 \pm 0.02^{\mathrm{d}}$ & $0.62 \pm 0.02^{\mathrm{b}}$ & $0.47 \pm 0.02^{\mathrm{c}}$ & $0.39 \pm 0.03^{\mathrm{d}}$ \\
\hline $\mathbf{4 8}$ & $2.12 \pm 0.04^{\mathrm{a}}$ & $0.73 \pm 0.02^{\mathrm{d}}$ & $0.95 \pm 0.03^{\mathrm{b}}$ & $0.80 \pm 0.03^{\mathrm{c}}$ & $0.69 \pm 0.03^{\mathrm{d}}$ \\
\hline $\mathbf{6 0}$ & $2.73 \pm 0.03^{\mathrm{a}}$ & $1.17 \pm 0.03^{\mathrm{d}}$ & $1.36 \pm 0.04^{\mathrm{b}}$ & $1.24 \pm 0.03^{\mathrm{c}}$ & $1.10 \pm 0.03^{\mathrm{e}}$ \\
\hline $\mathbf{7 2}$ & $3.62 \pm 0.04^{\mathrm{a}}$ & $1.49 \pm 0.03^{\mathrm{d}}$ & $1.79 \pm 0.04^{\mathrm{b}}$ & $1.56 \pm 0.03^{\mathrm{c}}$ & $1.42 \pm 0.03^{\mathrm{e}}$ \\
\hline
\end{tabular}

Means in a row followed by the same letter are not significantly different at $<0.05$. Data obtained from at least three replicates.

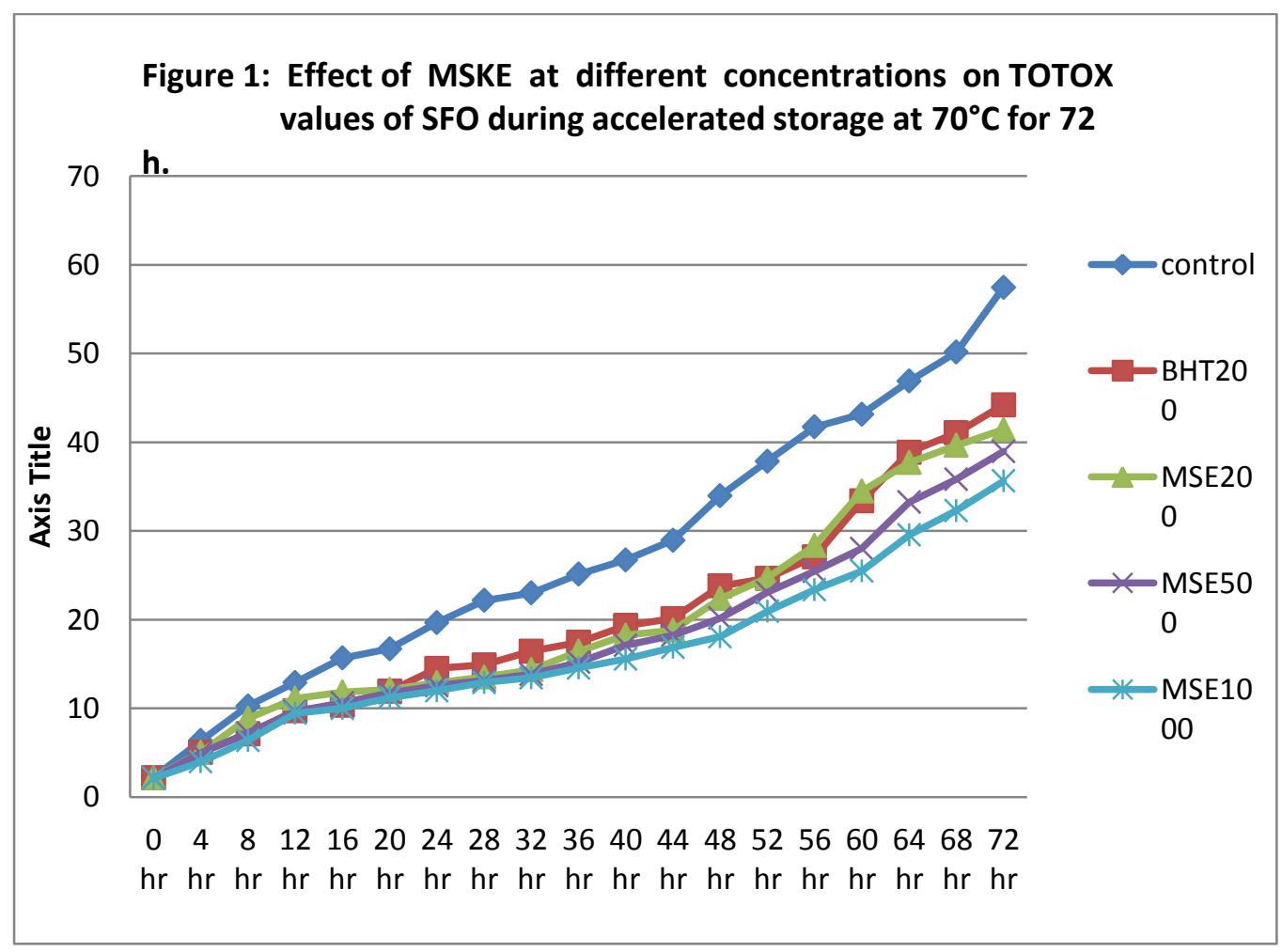




\section{ثقيميم مستخلص أنوية بذور المانجو كمضادات أكسده

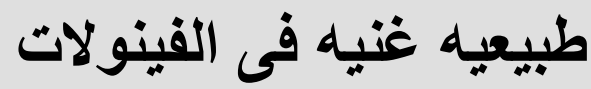

طلعت محمد عبد الرحمن القاضي '، محمد كمال عبد الرحمن '، عباس عمر طليبة ‘ و سامي محمد أبو المعاطي كمال عبد المعن

$$
\text { قسم علوم الاغذية اللتغذية ـ وزلية الزراعة الصحة جامعة الزقازيق }
$$

\section{الملخص العربى عباد النمب من}

زيت بذرة عباد الشمس من المصادر الغنية بحم اللبنوليك والذى بعتبر من اكثر العوامل المسبية لأكسدة

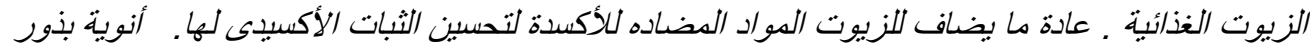

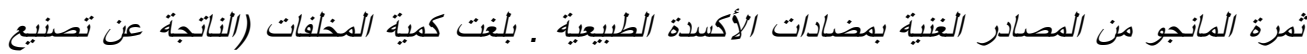

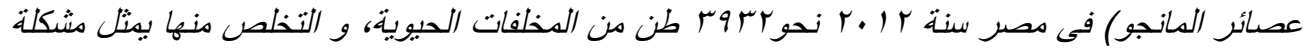

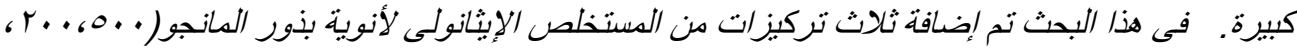

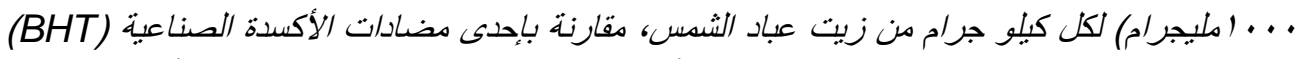

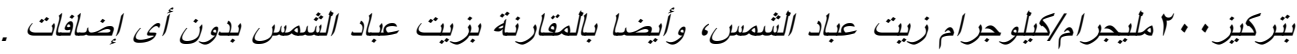

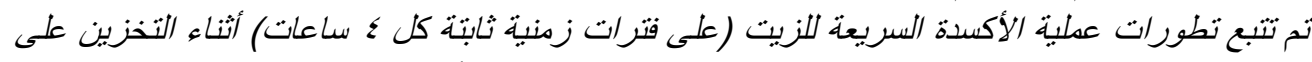

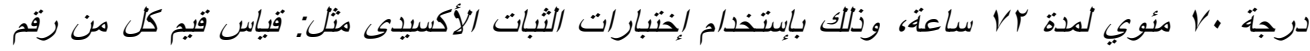

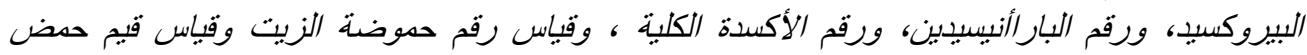

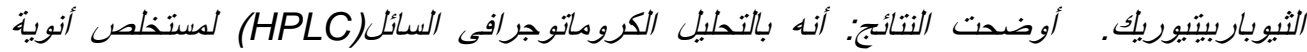

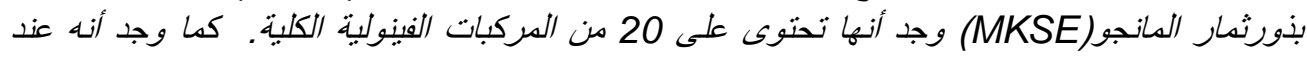

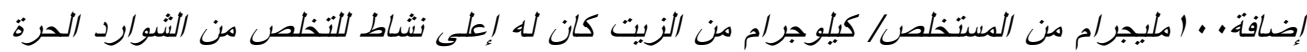

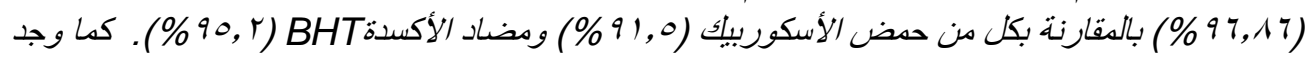

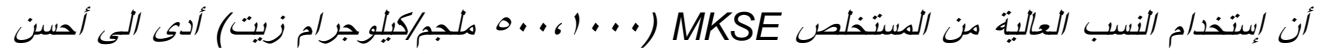

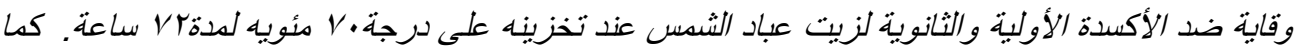

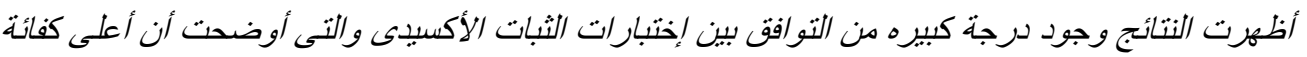

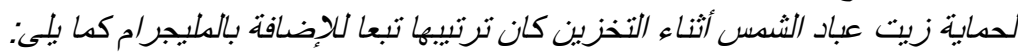
> MKSE200 > BHT200 > MKSE500 > MKSE I. . .

$$
\text { الكلمات المفتاحية: بذور المانجو - زبيت دوار الثمس - ثبات الأكسة }
$$

